\title{
Metadiscourse Resources across Themes of Islamic Friday Sermon
}

\author{
Israa Ismaeel Mahmood ${ }^{a}$ \\ redsun05555@yahoo.com \\ Department of English, \\ Faculty of Modern Languages and Communication, \\ Universiti Putra Malaysia, Malaysia \\ Zalina Mohd Kasim ${ }^{b}$ \\ zalina_mk@upm.edu.my \\ Department of English, \\ Faculty of Modern Languages and Communication, \\ Universiti Putra Malaysia, Malaysia
}

\begin{abstract}
Friday sermon is a formal speech delivered during the act of worship by the Muslims held before Friday prayer. It is a weekly event that involves disseminating information as well as persuading the congregation through preaching and teaching. In Friday sermons, as a rhetorical religious genre, religious orators usually try to convince an audience using different strategies and language devices such as metadiscourse. Metadiscourse is a rhetorical strategy used to achieve persuasive and communicative purposes as it helps writers (speakers) to engage their audience and guide their understanding of a text. To get insights into how metadiscursive devices contribute to the theme of a sermon, the current study aimed to examine the distribution of rhetorical devices frequency in three themes (belief, practice, and spiritual) of Islamic Friday Sermon (IFS) delivered in English. To achieve the aim of this study, Hyland's (2005) interpersonal model of metadiscourse was adapted to analyse metadiscourse devices that were deployed in thirty sermons (10 per theme) delivered between 2012 and 2018. The findings reveal the dominant presence of metadiscourse in the sermons of practice/action theme. This indicates the vital role of metadiscourse features in the nature of sermons as a teaching method. Revealing the status of MD rhetorical devises in three different themes can help raise awareness among orators on the appropriate use of MDMs to support the theme of a sermon and make their speeches meaningful, coherent and persuasive.
\end{abstract}

Keywords: Metadiscourse; sermons; theme; Islamic Friday sermon; rhetorical device

\section{INTRODUCTION}

Friday sermon or khutbah al-jumu'ah (in Arabic) is one of the most prominent types of Islamic religious discourse which has a significant impact on Muslim community. In fact, its message of mending social reality goes beyond Muslim's community and spreads out to the large society (Hashem, 2010, p. 49). Friday sermon is viewed as "a one-way communication through which the religious authority tells the audiences what to think and what to believe; in the process, the preacher appropriately addresses particular audiences in order to make them identify with the message, talking within a specific storyline in which a certain normative order is projected" (Mellor and Rinnawi, 2016, p. 91). Linguistically, the meaning of Friday sermon is conveyed through the improvised speech by articulate speakers talks addressing the masses with the intention to convince them (Mustafa et al., 2004). In addition, according to Onay (2004), Friday sermon affects listeners' minds and their orientations. Onay sees that sermon's message can be

${ }^{a}$ Main author

${ }^{b}$ Corresponding author 
realised through addressing three dimensions: belief/thought, practice/attitude, and spiritual/emotion themes (Onay, 2004).

With respect to sermons themes, it has been pointed out that a particular theme might include different choices of language that religious orators should be aware of. As stated by Davies "theme may be seen at a level between the grammatical constraints on allowable sentence patterns, and the high level, goal-oriented discourse constraints" (1988, p.179). The analysis of the theme allows the analyst to discuss linguistic choices which are crucial to the organisation, and interpretation of meaning. Metadiscourse is one of those choices which help orators construct a persuasive discourse and persuade listeners with their message; as well as help guide listeners through the theme by adding to the overall cohesion and coherence of the sermon. Metadiscourse involves organising the information and engaging the addressees to the discourse. As pointed out by Hyland (2005) "a text has to talk to readers or hearers in ways that they find familiar and acceptable, which means that the process of comprehension and participation are not just a matter of informational clarity, but of the individual writer's or speaker's projection of a shared context" (pp. 13-14). Metadiscourse is described by Hyland (2005) as a coherent set of elements and a rhetorical strategy used to obtain persuasion since it helps writers/speakers to engage their audience and guide their understanding of a text.

While metadiscourse has been investigated in a range of genres, only few studies dealt with examining metadiscourse features in sermonic discourse, particularly Islamic Friday sermon. So far no studies that dealt with the use of metadiscourse markers among the themes of Islamic Friday sermons have been found. Thus, this study is aimed at establishing a representative corpus and making it thematically comparable to analyse the influence of sermon's themes on the distribution of metadiscourse marker. The analysis of the language of the Islamic Friday sermon gives us an indicative picture of the situation of metadiscourse in religious discourse and shows how such linguistic features support the interactive and persuasive aims of the orators. Moreover, it gives an impression about the effect of the variation in the themes on the distribution of metadiscourse markers in the religious genre. Such results could be applied to the Islamic preaching domain. They could be helpful guidelines to the orators in sermon's preparation phase. In other words, when an orator equips himself with the knowledge of the functions of metadiscourse markers and considers the importance of audience perception in his choices of linguistics elements, he would be able to master the sermon's construction appropriately and achieve the communicative and persuasive goals of the sermon. As Hyland (2017) explains "because the successful management of these local rhetorical resources helps achieve immediate social and communicative objectives" (p. 17).

Simply put, by using Hyland (2005) metadiscourse taxonomy this research is carried out to reveal the use of the rhetorical devices of metadiscourse in the three different themes stated by Onay (2004): belief, practice and spiritual sermon. It also raises the awareness of orators about the appropriate use of metadiscourse markers in accordance with the themes they deliver. Furthermore, this study will be added to the few studies that have been made on metadiscourse in religious discourse of Friday sermon.

The study aims to answer the following questions:

1. To what extent do the religious orators use metadiscourse markers in the three themes (belief, practice and spiritual) of the selected sermons?

2. What are distinctions in the use of interactive and interactional metadiscourse markers in effectively conveying the themes in the sermons? 


\section{LITERATURE REVIEW}

The term metadiscourse was used in text structure studies. Several definitions were proposed for the term metadiscourse by many authors among which are: "Writing about writing" (Williams, 1981, p.212), "discourse about discourse" (Vande-Kopple, 1985, p.83) and "discoursing about the discourse" (Crismore, 1984, p. 280). According to Hyland (2005), metadiscourse refers to the linguistic devices used by the writer to organise a discourse or express his/her opinion about the content or the reader. He defines metadiscourse as "the cover term for the self-reflective expressions used to negotiate interactional meaning in a text, assisting the writer (or speaker) to express a viewpoint and engage with readers as members of a particular community" (2005, p.37).

The literature showed that metadiscourse has been studied in different texts and contexts by many scholars. For example, Hyland (1998) investigated MDMs in company annual reports; Bunton (1999) in post graduate dissertations; Hyland and Tse (2004) in academic writing; Loi and Lim (2019) in the discussion sections of English and Malay educational research article; and Azar and Hashim (2020) in the review article genre. Metadiscourse features are also examined in different disciplines and languages, for example Blagojevic (2004) and Dahl (2004). They are also scrutinised in non-academic spoken discourse as in parliamentary debates (Ilie, 2003), in Malaysian ESL job interviews (Turiman et al., 2018); and in non-academic written discourse specifically in fiction genre (AlJazrawi and AlJazrawi, 2019).

More recently, researchers have shown an increased interest in inspecting the use of metadiscourse markers in religious discourse. Where discourse of preaching is concerned, Boggel (2009) has studied metadiscourse in English Christian texts of the late Middle Ages and Renaissance. Another study was conducted by Malmström (2016) who investigated the use of metadiscourse in contemporary Christian preaching manuscripts as a form of social and communicative engagement. As for Islamic studies, Mahmood and Kasim (2019) adopted Hyland's (2005) model to explore the occurrence of metadiscourse resources in the Friday sermons delivered in English language. The results of the study revealed that metadiscourse were used extensively in the English sermons and the religious orators relied effectively on the interactional markers to achieve their aims of speech. Another recent study was produced by Abdel-Moety (2019) who examined the distribution and the function of metadiscourse in Arabic religious discourse, particularly, Arabic sermons using Ädel's (2010) model. Similar to Mahmood and Kasim's (2019) study, the results of Abdel-Moety's (2019) study showed that the linguistic devices of metadiscourse were employed heavily in the Arabic sermons. Besides, metadiscourse resources were used mainly to interact with the audience.

On the other hand, very few studies dealt with exploring the discourse of Islamic sermon based on their themes. One of those studies is that conducted by Onay (2004) who investigated the discourse of Turkish Friday sermons delivered in 1999. The study involved content analysis of 54 sermons from three dimensions: thematic analysis which involved examining the frequencies of each theme (belief, practice, and spiritual) sermons and the issues discussed in the sermons; the analysis of the semantic contexts through the occurring themes; and examining the textual styles. Another study was conducted by Albayrak (2012) which inspected the status of the Friday sermon in two central mosques in Melbourne. By relying on Onay's (2004) format of Islamic Friday sermon's themes, Albayrak compared the frequency of the sermons which address belief, behaviour, and spiritual themes that were delivered in the two mosques. So, in this study the importance of analysing the language in religious discourse based on their themes has motivated the researchers to set a cross themes study that examine the linguistic features used in Friday sermons. 


\section{METHODOLOGY}

This study adopted the theoretically robust and analytically reliable model of metadiscourse proposed by Hyland (2005). This is because Hyland (2005) reconsidered and developed the concept of metadiscourse to further elucidate distinction and classification of metadiscourse. Unlike Kopple (1985) and Crismore et al. (1993), Hyland rejects the distinctions of textual and interpersonal markers and he suggests that all metadiscourse is interpersonal. He (2005) explained that the interpersonal metadiscourse "can help us express our personalities and our reactions to the propositional content of our texts and characterize the interaction we would like to have with our readers about that content" $(2005$, p.26). Therefore, adopting Hyland's (2005) classification would help the researchers to have insight on how such linguistic resources perform in different themes of the sermonic discourse. Hyland (2005) classified metadiscourse into two main categories: the 'interactive and interactional' metadiscourse. Table 1 below represents Hyland (2005) interpersonal model of metadicourse:

TABLE 1. Hyland's (2005) model of metadiscourse

\begin{tabular}{lll}
\hline Category & Function & Examples \\
\hline Interactive & Help to guide the reader through the text & Resources \\
Transitions & express relations between main clauses & in addition, but, thus, and \\
Frame markers & refer to discourse acts, sequences, or stages & finally, to conclude, my purpose is \\
Endophoric markers & refer to information in other parts of the text & noted above, see Fig, in section 2 \\
Evidentials & refer to information from other texts & according to X/ (Y, 1990) Z states \\
Code glosses & elaborate propositional meanings & namely, e.g., such as, in other words \\
Interactional & Involve the reader in the text & Resources \\
Hedges & withhold commitment and open dialogue & might, perhaps, possible, about \\
Boosters & emphasize certainty or close dialogue & in fact, definitely, it is clear that \\
Attitude markers & express writer's attitude to proposition & unfortunately, I agree, surprisingly \\
Engagement markers & explicitly build relationships with reader & can see that, note, consider \\
Self-mentions & explicit reference to author(s) & I, we, my, our \\
\hline
\end{tabular}

The interactive metadiscourse concerns with guiding the listeners through the use of discourse to organize the text, while interactional metadiscourse engages the listeners through the use of discourse to handle the social relationship (Hyland, 2005). The former category is subdivided into transitions, frame markers, endophoric markers, evidentials and code-glosses, while, interactional metadiscourse is subdivided into hedges, boosters, attitude markers, engagement markers and self-mentions.

The first interactive markers are transitions. They are mostly adverbial phrases and conjunctions used to help audience "interpret pragmatic connections between the steps in an argument" (Hyland, 2005, p. 50). They could act as (i) the form of additive devices, such as and, moreover, by the way, etc.; (ii) comparative devices, such as similarly, however, but, etc.; and (iii) consequence devices, such as anyway, of course, admittedly, etc (Hyland, 2005, p. 50). The second resources are frame markers. They indicate text boundaries and they help addressees to follow the structure of the text. They perform several actions (Hyland, 2005, p. 51) for example, they can be used to (i) sequence sections of the text or record the events in time through sequencers, such as first, then, $a / b$, and next; (ii) label the stages of the text, such as in sum, to conclude, and summarizing; (iii) signal topic shifts through the use of language expressions, such as right, now, and well; and (iv) announce the aims of the discourse through the use of some instances, such as the purpose is, intend to, and want to. Endophoric markers are the third type of the interactive resources. They are expressions which are used to refer to other sections of the text to support the audience's understanding, such as see figure, as shown 
above, and refer to the next section. The last interactive markers are code glosses. They are utilized to provide additional information by "rephrasing, explaining or elaborating what has been said" to support audience's perception of the addresser's intended meaning (Hyland, 2005, p. 52), and include examples such as in other words, this is called, for example, it means, and this indicates.

On the other hand, the first interactional markers are hedges. They are the resources which show the addresser's decision to emphasise other viewpoints and present information as an opinion rather than a fact (Hyland, 2005, p. 52). The use of hedges can be realised through the use of epistemic verbs (seem, predict, and suggest); epistemic nouns (doubt, possibility, and uncertainty); epistemic adverbs (generally, perhaps, and usually); approximators (around, about, and approximately); and modals (can, may, should, and would) (Tan, 2011; Khedri, 2014). Unlike hedges, boosters are utilized to close down alternatives and present the certainty of the addresser's voice. Boosters are signalled through the use of various forms (Khedri, 2014). For example, boosters can be represented in the form of verbs (believe, know, trust and proof); adverbials (completely, exactly, literally, and no doubt); and superlatives (the most, the best, and the greatest). The third type of the interactional resources is attitude markers. They indicate the addresser's affective meanings, and can be signalled through the use of verbs such as agree and encourage; adverbs such as unfortunately and hopefully; and adjectives such as serious and beautiful (Tan, 2011; Khedri, 2014). Self-mention or the presence of the addresser in the context is the fourth type of the interactional markers which was absent in the previous models (Vande-Kopple, 1985; Crismore et al., 1993). Hyland (2005) sees that self-mention allows writers/ speakers to interfere into the text and provide comments in relation to the proposition of the text, thus, self-mention performs metadiscoursal function. Self-mention is signalled through the first-person pronouns and possessive adjectives, such as $I, m y, m e$, we, our, and so on. The last subcategory of the interactional markers is engagement markers which involve addressing the audience explicitly in the context to gain their attention or to show solidarity by including them as discourse participants, such as the use of personal pronouns as you, your, we. The writers/ speakers can also employ engagement markers rhetorically through the use of questions and imperatives, such as do you, what does that mean? note, see, remember, and so on.

These markers might act as non-metadiscoursal and perform as a propositional content. Thus, Hyland's (2005) model is based on three principles through which metadiscourse markers can be identified (pp. 37-48): "(i) Metadiscourse is distinct from prepositional aspects of discourse; (ii) Metadiscourse expresses writer-reader interactions; (iii) Metadiscourse refers only to relations which are internal to the discourse."

To identify the themes of a sermon, this study mainly relied on classification by Onay (2004). Onay's (2004) classification has been selected mainly due to its simplicity and also the fact that to date, no studies have been found to have dealt with sermons' themes categorisation. Onay's (2004) classification includes categorising sermons according to their themes (belief/thought, practice/action, and emotion/spiritual). According to Onay's (2004) format:

(i) In the sermons of belief/thought dimension, topics that estimate listeners thinking to believe are dominant and repeat frequently, such as (believe in God, prophet, and Quran; believe in one God; knowing Allah from Quran's chapters; Islam and Christianity; purpose of life).

(ii) Action/practice sermons concern Muslim's behaviour and practices that they act based on the creed of Islam, such as (pilgrimage, prayers, fasting, halal and haram, drinking, lying, modesty). In this type of sermons, orators direct their listeners, advise them, explain and teach through preaching.

(iii) Spiritual sermons estimated listeners' emotion and the psychological affairs that related to the faith, such as (Happiness, repentance, the signs of the Day of Judgment, believe in hereafter, fear of God, hell and paradise). 
All the names of the orators, the titles of the sermons, and the words number of the selected sermons are enlisted in the table below:

TABLE 2. The names of the orators, the titles of the sermons, and the word count of the selected sermons

\begin{tabular}{|c|c|c|c|}
\hline No. & Orators' names & Belief/ Thoughts & word count \\
\hline 1 & Nouman Ali Khan & A divine remedy from surat al Ma'arij & 4,477 \\
\hline 2 & Othman Lateef & $\begin{array}{l}\text { Acknowledge Allah with gratitude (Sura Al } \\
\text { Kahf) }\end{array}$ & 3,310 \\
\hline 3 & Nuradeen Ahmed & Be like Muhammad! & 1,460 \\
\hline 4 & Abdul Nasir Jangda & $\begin{array}{l}\text { Defending the Honor of the Prophet } \\
\text { Muhammad }\end{array}$ & 4,674 \\
\hline 5 & Omar Galal & lessons from surra- al -Araf & 6,546 \\
\hline 6 & Abdullah Hakim Quick & Lessons from today's world & 3,557 \\
\hline 7 & Atif Jung & Muslim and Christian & 4,273 \\
\hline 8 & Bilal Philips & Purpose of life & 3,979 \\
\hline 9 & Ahsan Hanif & $\begin{array}{l}\text { The single greatest verse in the Quran Ayat-ul- } \\
\text { kursi }\end{array}$ & 4,653 \\
\hline 10 & Arshad Gamiet & Trust Allah & 2,902 \\
\hline No. & Orators' names & Actions/ Attitudes & word count \\
\hline 11 & Ammar Alshukry & charity & 1,990 \\
\hline 12 & Essam Mahgoub & Don't blame others, blame yourself first & 2,700 \\
\hline 13 & Abu Easa Niamatullah & Establishing family success & 4,681 \\
\hline 14 & Yaser Birjas & Hajj: The Time is Now & 3,576 \\
\hline 15 & Waleed Basyouny & How to maximize the benefits of jumu'a & 3,833 \\
\hline 16 & Husni Hammuda & Managing change effective & 2,956 \\
\hline 17 & Navaid Aziz & My identity I am Canadian & 3,030 \\
\hline 18 & Yasir Qadhi & Syria Crisis & 6,671 \\
\hline 19 & Hamza Yusuf & The crisis of ISIS & 4,772 \\
\hline 20 & Alyas Karmani & $\begin{array}{l}\text { Together Against Grooming group Tackling } \\
\text { Street Grooming in the UK }\end{array}$ & 4,874 \\
\hline No. & Orators' names & Spirituality/ Emotions & word count \\
\hline 21 & Munawar Haque & Belief in hereafter & 2,098 \\
\hline 22 & Abu Taleb & Daring to Dream in Times of Despair & 3,106 \\
\hline 23 & Omar Suleiman & Istigfar (repentance) & 4,055 \\
\hline 24 & Hussam Roushdi & Life and death & 2,208 \\
\hline 25 & Muhammed Faqih & $\begin{array}{l}\text { Meaning of taqwa (from the first khutbah of the } \\
\text { prophet) }\end{array}$ & 1,789 \\
\hline 26 & Yahya Ibrahim & positivity & 3,109 \\
\hline 27 & Mohammed Mana & The blessing of tongue & 3,408 \\
\hline 28 & Suleiman Salim & The day of judgment & 4,906 \\
\hline 29 & Kammal Makki & The meaning of Atauadua' in Islam & 3,464 \\
\hline & & Within darkness, there is always light & 3,221 \\
\hline \multicolumn{3}{|c|}{ Total number of the words in the selected sermons } & 110,278 \\
\hline
\end{tabular}

\section{THE CORPUS}

From a discourse perspective, the use of a corpus offers better understanding of the characteristics of the written or spoken discourse. According to Paltridge (2012, p.144) a corpus is "a collection of spoken or written authentic texts that is representative of a particular area of language use, by virtue of its size and composition". Thus, this study has built a corpus of 30 English Islamic Friday sermons (ten for each theme section). The analysis includes the message (body) of sermon, and the opening and closing part of prayers are excluded because both act as regular formula in the structure of a sermon. Table 3 provides a detailed description of the corpus analysed. It shows the number of sermons in each corpus, the range of the length of a sermon in each dimension, the total number of words in each theme's category, and total size of the collected data. 
TABLE 3. Description of the sermonic data

\begin{tabular}{cccc}
\hline & Belief/ Thought & Action/ Practice & Emotion/ Spiritual \\
\hline $\begin{array}{c}\text { No. of sermons } \\
\text { The range of the length of } \\
\text { any sermon }\end{array}$ & 10 & 10 & 10 \\
$\begin{array}{c}\text { The total number of words } \\
\text { Total size of the data }\end{array}$ & 39,831 & $1,990-6,671$ & $1,789-4,906$ \\
& & 39,083 & 31,364 \\
\hline
\end{tabular}

\section{DATA COLLECTION}

Ten sermons for each theme were selected using quota sampling. This sampling strategy has been used because it allows the researchers to sample subgroups that are of the great interest to the study, as well as allows the researchers to observe the relation between the subcategories (Whitehead et al., 2016). Since Friday sermons are normally delivered in Arabic language and there are only a few websites that publish Islamic sermons delivered in English language, the researchers have compiled the data from different sources, specifically, from khutbahbank website, muslimsmatters magazine website and Amaghrib orators' sermons that have been uploaded on youtube. These websites include positive, informative and inspiring sermons; sermons that refuse any acts of terrors and address non-Muslims respectfully; and sermons delivered by qualified international religious orators.

However, before categorising the themes of the sermons, it was necessary to download the collected audio-video sermons and to transcribe them in order to obtain the transcripts of the sermons. A native speaker of English was enlisted to check the transcripts by comparing them to the spoken version. Then, the categorisation of the themes started with analysing the titles of the sermons since we can identify the intended purposes of the sermon from the titles. As Addison (1999) noted, the title tells you what the text is about. The sermons were then read carefully and some notes, key words, topics, essential themes and concepts were noted down. To simplify the identifying of the themes in this study, we hypothesised three questions related to the relationship between sermon's message and orientations which is stated by Onay, (2004, p. 4). The questions are: (i) does sermon's message concern thoughts, beliefs and assumptions? (the orator asks his listeners to believe or not to believe); (ii) does sermon's message concern behaviour, action and practices? (the orator asks the listeners to act or not to, based on Islamic creed); (iii) does sermon's message concern spiritual feelings? (the orator asks the listeners to fulfil the expectation from god). The answers of these questions help in determining the theme of the sermons. Although this method does not provide a full content analysis, it fulfilled the goal of this research and offered an idea of the type of theme of each sermon.

\section{ANALYTICAL PROCEDURE}

The texts of the three themes of the sermons were analyzed electronically by applying them into MonoConc Pro 2.2 software (Barlow, 2003) to identify the occurrence of the complete metadiscourse markers provided in Hyland's (2005) model, and to find out their frequencies. The search included all the metadiscourse items in Hyland's (2005, pp. 218-224) items list. However, as noted by Tan (2011) "Although Hyland's (2005) list of metadiscourse was a list of search items on metadiscourse for his book, the new additional of the forms of metadiscourse would make Hyland's (2005) existing search items of metadiscourse more comprehensive" (pp. 239-240). Therefore, some additional items of metadiscourse that were identified by earlier studies (Tan, 2011; Khedri, 2014; Lee and Subtirelu, 2015) were also included in this study. 
The texts of the selected sermons were read thoroughly and carefully in order to observe whether new additional items related to religious discourse were present. For example, the item okay does not exist in Hyland's items list (2005, pp. 218-224), but it is identified as frame marker of metadiscourse by Lee and Subtirelu (2015) since "it refers to discourse acts, sequences or stages" (Hyland, 2005, p. 49). Another example is the vocative brothers and sisters in the sermonic discourse, which was considered by the researcher as engagement marker since they "explicitly build relationship with reader" (Hyland, 2005, p. 49). It should be noted that, all the additional items were identified according to the three key principles proposed by Hyland (2005, pp. 37-48), and they also fulfil the functions of metadiscourse markers that were highlighted in the table of Hyland's (2005) model.

By applying the items of the different metadiscourse categories into MonoConc program, the concordance lines showed their occurrence in the discourse and counted their frequencies. For example, Figure 1 shows the concordance lines of the transition element but, the occurrence of each identified but in its context in the sermon, and the frequency of the item but in the text.

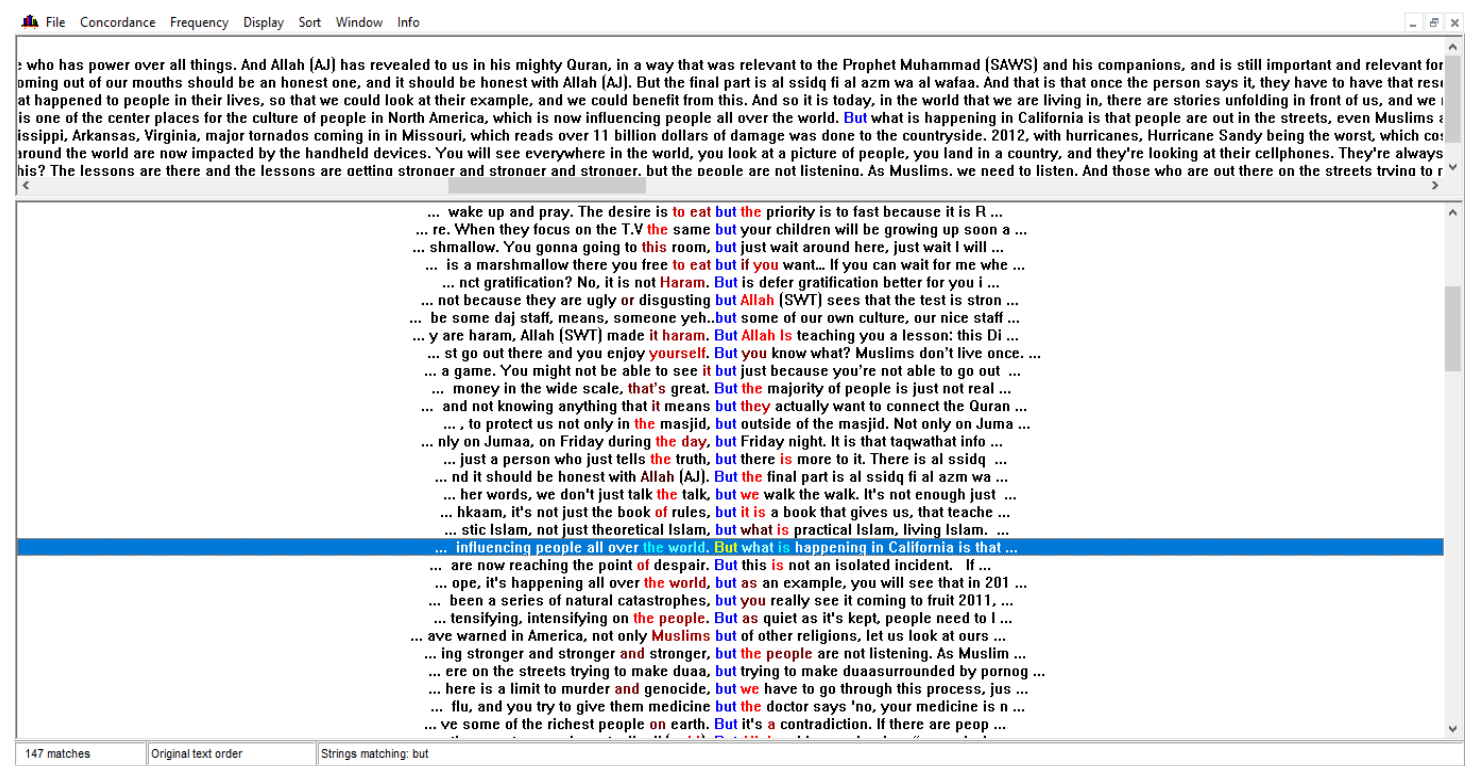

FIGURE 1. The concordance lines of the transition element but

Then, to code the markers, all the identified items were carefully coded manually by the researcher, item-by-item, and line-by-line. The stances that appeared in MonoConc lines were examined in their context to see whether they serve metadiscoursally in the discourse or they performed as proposition content (see the three key principles of Hyland, 2005, pp. 3748). Through the use of deletion aspect of MonoConc, all the stances that performed nonmetadiscoursally were deleted.

Finally, since the selected sermons are of different lengths, the researchers have standardized the frequencies to occurrences per 1000 words (ptw) to allow comparison across corpora of unequal sizes. The formula for the counting the frequency is as follows:

$$
N=\frac{(\text { number of } x)(1000 \text { words })}{\text { Total number of words }}
$$




\section{RESULTS AND DISCUSSIONS}

\section{THE OVERALL FREQUENCY OF METADISCOURSE IN THE THREE THEMES OF THE SELECTED SERMONS}

To answer question 1 of this study, Table 4 presents the overall frequency of the occurrence of metadiscourse and its two main categories (interactive and interactional markers) among the three themes (belief/ thought, action/ practice, and emotion/ spiritual) of the Islamic Friday sermons.

TABLE 4. The frequency of MD among the themes of IFS

\begin{tabular}{cccccccccc}
\hline & \multicolumn{3}{c}{ Belief/ Thought } & \multicolumn{3}{c}{ Action/ Practice } & \multicolumn{3}{c}{ Emotion/ Spiritual } \\
& Freq. & $\mathbf{\%}$ & ptw & Freq. & \% & ptw & Freq. & \% & ptw \\
\hline Interactive & 2,117 & 35.8 & 53.1 & 2,350 & 37.04 & 60.1 & 1,635 & 35.6 & 52.1 \\
Interactional & 3,789 & 64.2 & 95.1 & 3,994 & 62.95 & 102.2 & 2,954 & 64.4 & 94.2 \\
Total metadiscourse & 5,906 & & 148.3 & 6,344 & & 162.3 & 4,589 & & 146.3 \\
\hline
\end{tabular}

The distribution of metadiscourse resources in the three content themes of sermonic discourse varied. In the sermons related to belief/ thought there were 5,906 items. Of this total, 2,117 of the interactive metadiscourse markers were used to help guide the listeners through the discourse, and 3,789 interactional metadiscourse markers were used to involve the listeners in the argument. While the number of metadiscourse items was 6,344 in the sermons of action/practice dimension of which 2,350 were interactive and 3,994 were interactional metadiscourse items. In the sermons of emotion/spiritual dimension, the number of metadiscourse items used was 4,589. The interactive markers formed 1,635 of that total, and 2,954 of the markers used presented interactional metadiscourse.

It is obvious that across the three themes, interactional markers are utilised more frequently than interactive markers. This could be due to the fact that in face to face interaction speakers are inclined to affect their listeners through engaging them into the argument (Cavalieri, 2011; Ädel, 2012); in the case of Friday sermons, the interactional features contribute into establishing affective and credible appeals of persuasion and this in turns serves Friday sermon's purposes (Mahmood and Kasim, 2019). Table 4 also reveals a difference across the three content themes of the sermons in terms of the distribution of metadiscourse markers where they are deployed most frequently in the sermons of action/ practice dimension. This elucidates the significant role of such rhetorical devices in sermons of teaching nature. The variation in the size of the data among the three corpora might explain the differences of the existence of metadiscourse across the spiritual and the two other themes of sermons. Less metadiscourse resources are needed in short texts (Khedri, 2014). Across the three themes of sermons, the orators used interactive markers, the highest being 60.1 tokens per 1000 words to express the practice dimensions of the sermons, 53.1 tokens per 1000 words, and 52.1 tokens per 1000 words for sermons related to belief and thought, respectively. This suggests that the orators showed a strong inclination to closely guide the congregation through the sermons which deal with the principle of Islam, with themes that range from more practical actions or routines such as Hajj, prayers to ethical and moral issues such as establishing family or grooming. The employment of interactive metadiscourse markers provides logical connection of the propositions and lends further coherence to the explanations to assist the audience in understanding the sermons.

Similarly, the religious orators showed a remarkable interest in the use of interactional metadiscourse markers through the delivery of action/ practice sermons (162.3 cases per 1000 words) while, they appeared to be less frequently used in the belief and spiritual sermons (148.2 vs. 146.3 cases per 1000 words, respectively). The high rate of interactional markers in practice 
themes reflects the vital role of engaging the audience into propositions that are related to social issues and the manner in which Muslims should behave based on Islamic religion.

\section{THE FREQUENCY OF INTERACTIVE AND INTERACTIONAL METADISCOURSE IN THE THREE THEMES OF THE SELECTED SERMONS}

To answer question 2 of the current study, the total distributions of interactive, interactioinal markers and their subcategory were presented.

\section{INTERACTIVE MARKERS}

From Table 5, it is obvious that there is a number of differences in the distribution of interactive markers in the selected Islamic Friday sermons. Among the subcategories of interactive markers, transitions were highly presented in the three themes of the Islamic Friday sermon. Frame markers, evidentials and code glosses were deployed nearly in similar rates in the selected sermons, while the least used interactive maker was endophoric markers. However, across the three themes, transitions and code glosses markers were deployed frequently in the sermons of action dimension in which the orators are required to be clear and understandable since they teach and direct their listeners about the practice in the religion more than they preach. On the other hand, there is no significant differences in the distribution of frame markers, endophoric markers, evidentials across the three themes of IFS.

TABLE 5. The frequency of interactive markers across the themes of IFS

\begin{tabular}{lllllll}
\hline & \multicolumn{2}{c}{ Belief/ thoughts } & \multicolumn{2}{c}{ Practice/ actions } & \multicolumn{2}{c}{ Spirituality/ emotions } \\
Interactive markers & Freq. & ptw & Freq. & ptw & Freq. & ptw \\
\hline Transitions & 1,435 & 36.0 & 1,560 & 40.0 & 1,019 & 32.5 \\
Frame markers & 203 & 5.1 & 193 & 4.9 & 173 & 5.5 \\
Endophoric markers & 13 & 0.32 & 11 & 0.28 & 7 & 0.22 \\
Evidentials & 228 & 5.7 & 261 & 6.7 & 191 & 6.1 \\
Code glosses & 238 & 6.0 & 325 & 8.3 & 245 & 7.8 \\
\hline
\end{tabular}

However few variations were demonstrated in the distribution of the forms of the interactive markers' subcategories. Figure 2 presented the occurrence of the distribution of transition's forms across the three themes. In all the themes additive markers were used heavily to help the audience catch up with the orators' talk and to track the sermon's propositions effectively (Mahmood and Kasim, 2019). In addition, there is a slight difference in the distribution of the frequency of the consequence, comparison, and additive devices across the three themes of the selected sermons.

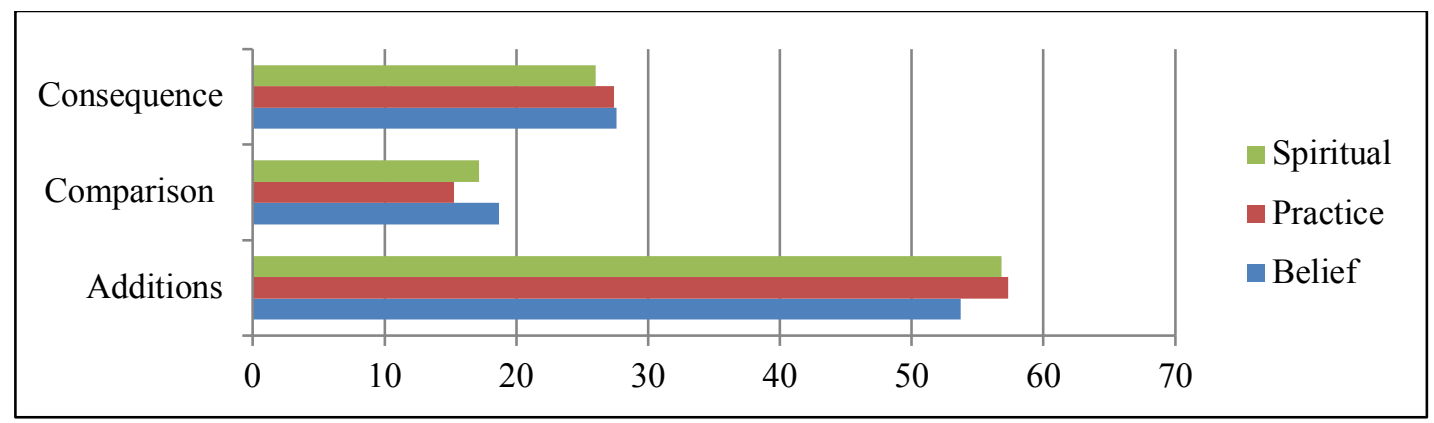

FIGURE 2. The distribution of the transitions' forms across the themes of IFS 
As for frame marker's forms, which are shown in Figure 3, the topic shift and sequence devices were the main forms used by the orators to express frame markers across the themes. This confirms the fact that these two discourse markers are crucial in communicating propositions regardless of the themes of sermons. However, it appears that the markers used to announce the discourse goals are used most frequently when the orators expressed practice or themes about virtue and behaviour (23.8\%) compared to the other two themes (belief $(15.3 \%)$ and spiritual themes (18.5\%). While declaring aims is crucial in any types of discourse, the higher use of announcing the discourse goal markers in sermons expression action and practice magnifies the needs of this kind of sermon to ensure that the audience's attention to the focus on the objective of the discourse.

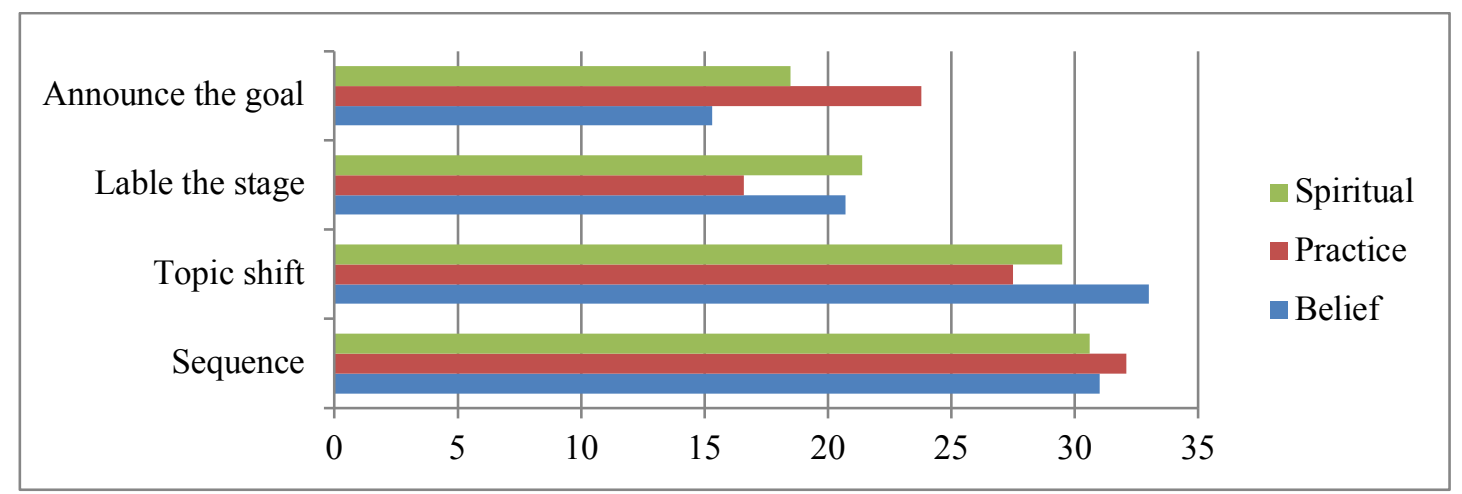

FIGURE 3. The distribution of the forms of frame markers across the themes of IFS

On the other hand, evidential marker showed an evident variation in the distribution of its forms across the three themes (see Figure 4). In the three themes of Islamic Friday sermons, providing evidence from the scripture (Quran) was the key feature used by the orators. For the delivery of the sermons of belief/ thought dimension, the religious orators utilized evidentials to relate the subject to the scripture $46.1 \%$ as well as life experience $26.8 \%$ more than in the sermons of action (35.6\% vs. $18.4 \%$, respectively) and spiritual themes $(39.8 \%$ vs. $15.7 \%$, respectively). This could be because most of the belief's sermons invite listeners to think of and realise the wisdom of Quran and relate this thinking with the real life experiences (Onay, 2004). In other words, relying more on presenting the stance of the holy book (which represents the divine stance) and the stance of people (which represents the real life) towards particular thought or belief helps the orators to achieve credibility and in turns persuade the listeners. The communicative function of the prophet's sayings is emphasised through its frequent use in the practice sermons $(30.3 \%)$, where this evidential form is employed to exhibit the prophet's attitudes towards certain practices and to teach the listeners how the prophet dealt with problematic issues. With regards to the citation of narration, it can be noticed that it occurred almost similarly in the three themes (18\% in belief, $15.7 \%$ in action, and $19.9 \%$ in spiritual sermons). 


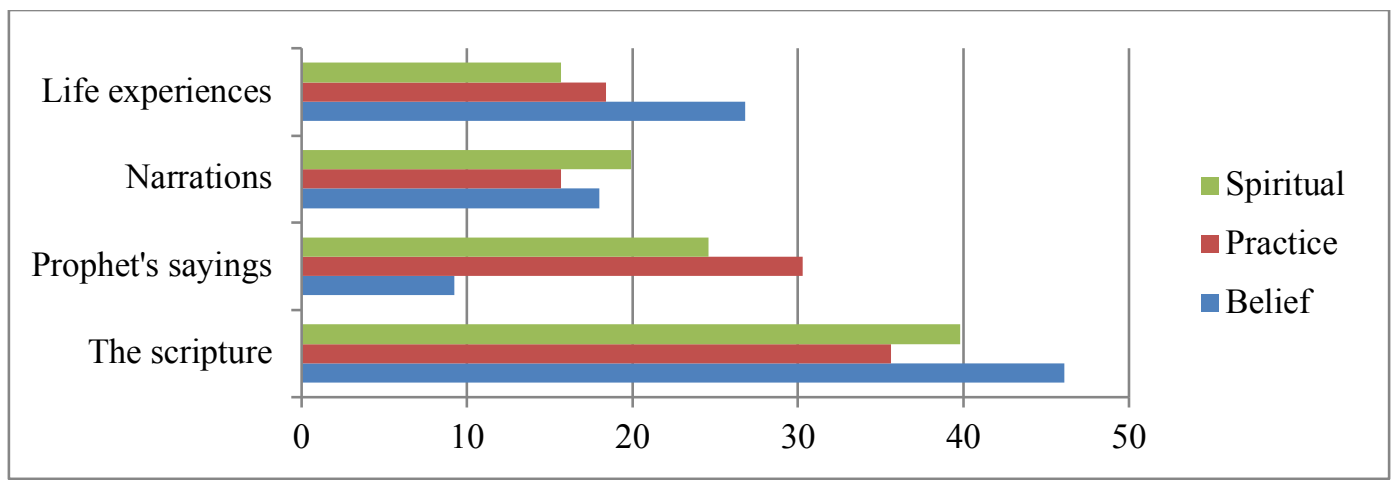

FIGURE 4 The distribution of the evidentials' forms across the themes of IFS

\section{INTERACTIONAL MARKERS}

Table 6 shows the distribution of the occurrence of interactional markers among the three themes of Islamic sermons. Among all the themes, engagement marker is the dominant feature of metadiscourse. This indicates the vital role of engagement markers in assisting the orators to show their solidarity and membership to the listeners, as it helps to "establish the one way communication based on the Islamic concept of brotherhood in the Friday sermon event" (Mahmood and Kasim, 2019, p. 96). In addition, the attitude markers were deployed more frequently in the sermons under the practice theme category (11.7 per 1000 words) than in belief and spiritual themes ( 8.6 and 9.5 per 1000 words, respectively). This could be due to the fact that this type of sermon is informational which is delivered to convince listeners to follow the Islamic principles (Onay, 2004). The use of attitude markers allows the orators express their position in the proposition and provide personal evaluation to strengthen their argument and create a rhetorical effect to persuade their listeners.

TABLE 6. The frequency of interactional markers across the three themes of IFS

\begin{tabular}{lllllll}
\hline & \multicolumn{2}{l}{ Belief/ thoughts } & \multicolumn{2}{l}{ Practice/ actions } & \multicolumn{2}{l}{ Spirituality/ emotions } \\
Interactional markers & Freq. & ptw & Freq. & ptw & Freq. & ptw \\
\hline Hedges & 382 & 9.6 & 393 & 10.1 & 341 & 10.9 \\
Boosters & 761 & 19.1 & 797 & 20.4 & 581 & 18.5 \\
Attitude markers & 342 & 8.6 & 459 & 11.7 & 298 & 9.5 \\
Self-mention & 224 & 5.6 & 387 & 9.9 & 159 & 5.1 \\
Engagement markers & 2,080 & 52.2 & 1,958 & 50.1 & 1,575 & 50.2 \\
\hline
\end{tabular}

For the hedges, Figure 5 shows that how the modals were deployed most frequently across the belief, practice, and spiritual sermons $(64.4 \%, 68 \%$, and $63.3 \%$, respectively). It seems that nouns were the least frequently employed form across the three themes of the selected sermons. Nonetheless, generally in all of the three themes of the selected sermons, the occurrence of each of the five forms of hedges is quite similar. 


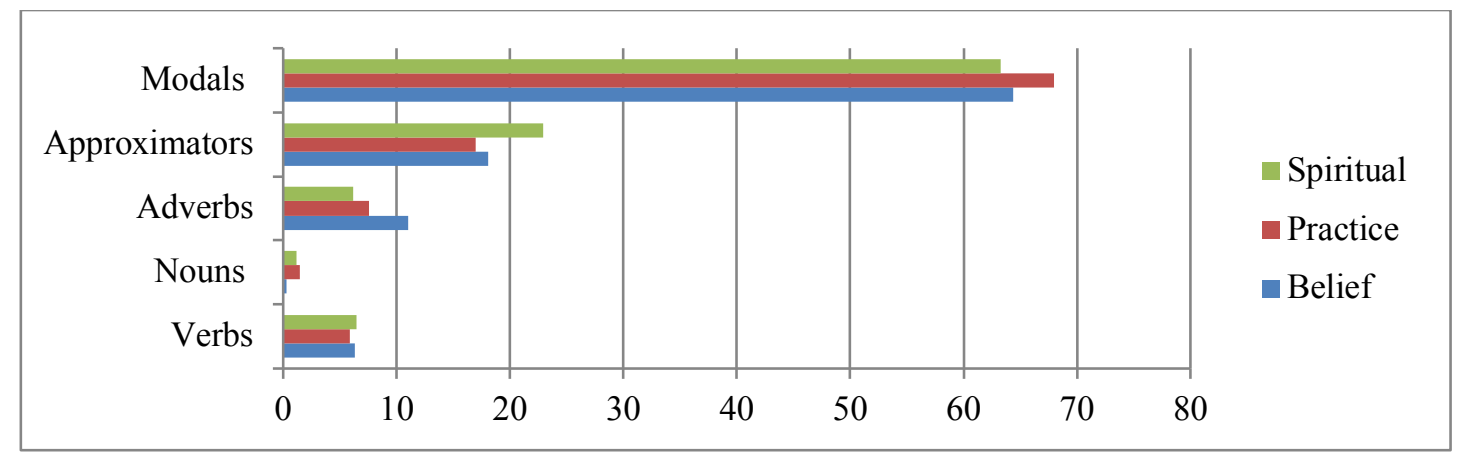

FIGURE 5 The distribution of the forms of hedges across the themes of IFS

Figure 6 reveals different range of frequencies where the use of seven subcategories of boosters in the three themes is concerned. It is noticeable that the orators exploited the use of modal devices heavily (37.9\%) in expressing the sermons of spiritual theme. The results of the analysis show that the modal 'will' which was mainly used to refer to future probabilities formed $79.5 \%$ of the total modals in sermons with spiritual themes. Adverbs on the other hand, were the favored form in sermons of belief and action themes. Verbs were employed more frequently in the action-themed sermon $(20.3 \%)$ than in belief-themed sermons $(17.1 \%)$, while the least usage of verbs can be observed in the spiritual-themed sermons (13.8\%). Similar occurrence of quantifiers is found in both action and spiritual sermons (14.6\%) and this was slightly less than those employed in belief sermons (18.7\%). All these variations might reflect the nature of each type of theme and how the religious orators can take the advantages of the linguistic features to support sermons' purposes.

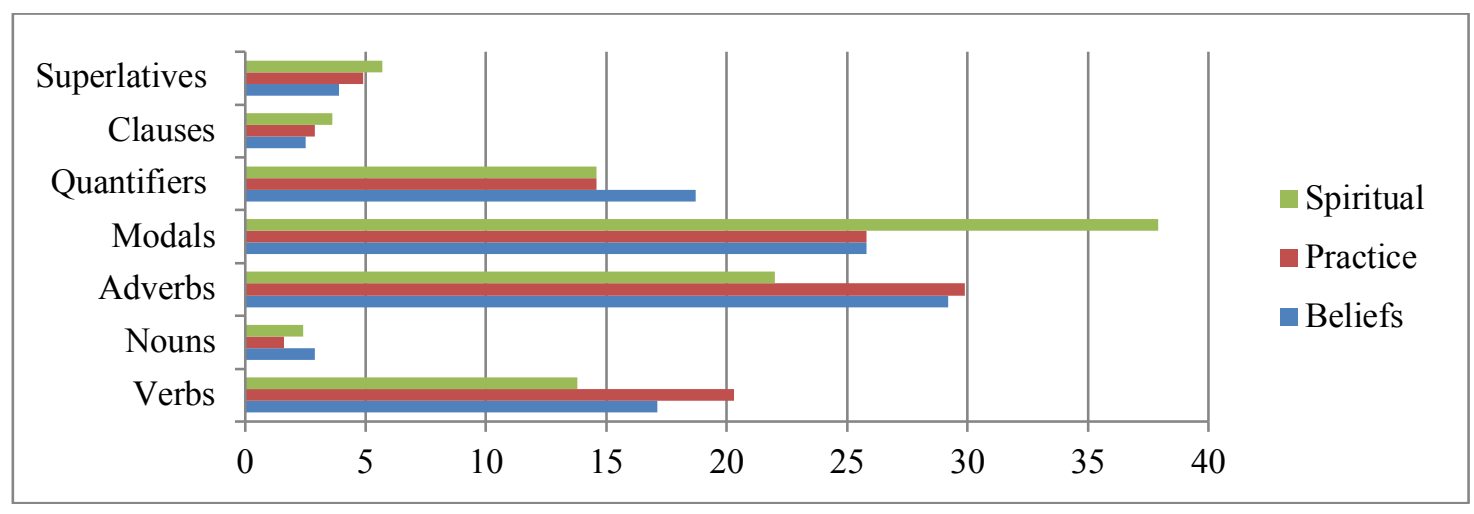

FIGURE 6 The distribution of the forms of boosters across the themes of IFS

As for the forms of attitude marker, adjectives were the most frequently used form in the three themes especially in the belief dimension $(67.8 \%)$. There is no significant variation in terms of the distribution of the frequency of the verbs and adverbs forms across the three themes see Figure 7). 


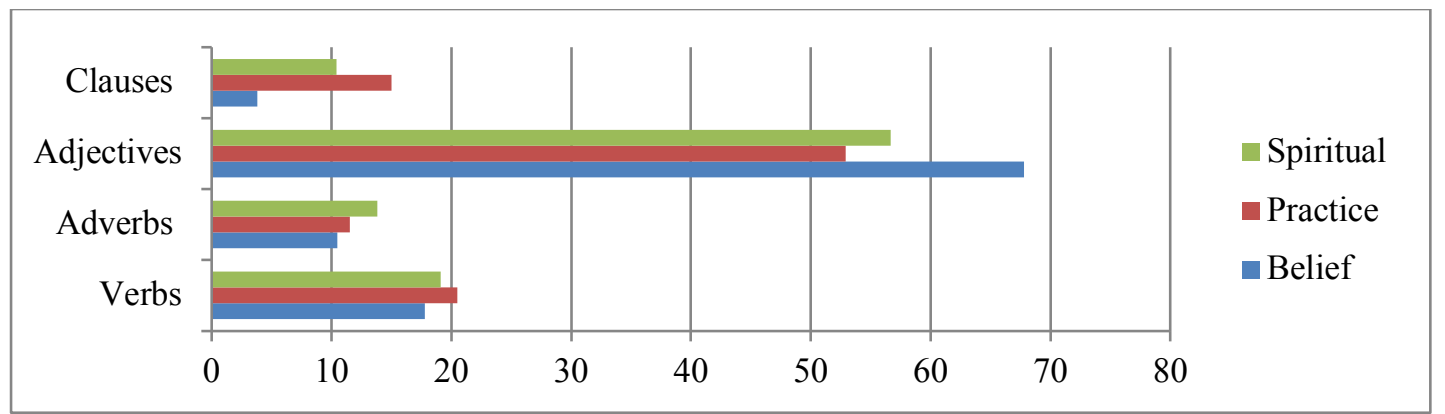

FIGURE 7. The distribution of the forms of attitude markers across themes of IFS

Figure 8 shows that engagement markers presented in the form of listener pronoun is the most frequently used across the three themes, especially the belief and spiritual sermons (84.6\% and $84.7 \%$, respectively). In contrast, both the directives and question forms were used less frequently (less than $10 \%$ of occurrence of the engagement marker), while the vocative form is the least frequently used form across the three themes.

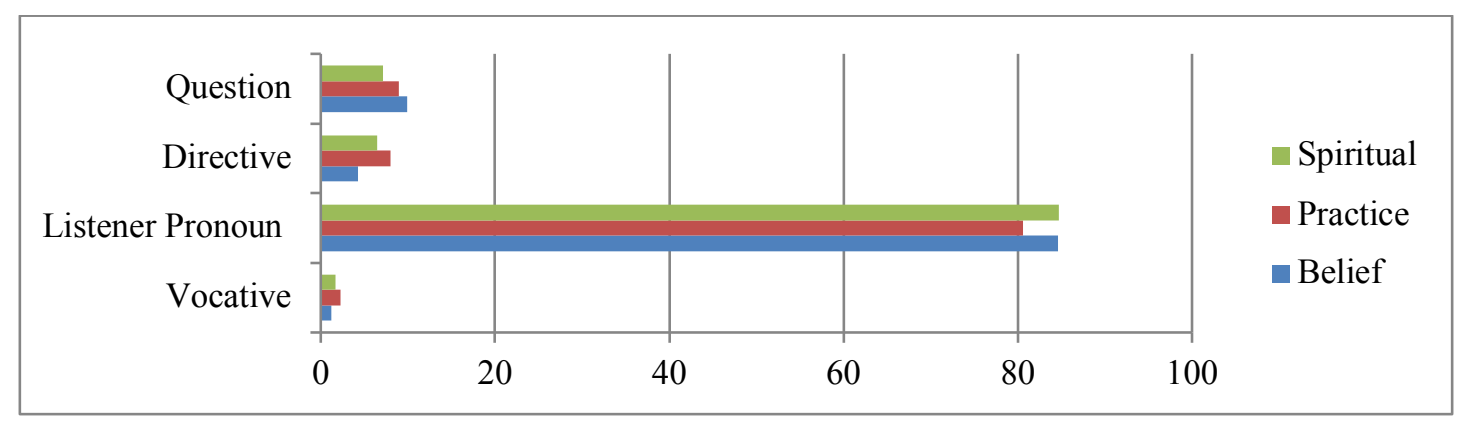

FIGURE 8. The distribution of the forms of engagement markers across themes of IFS

\section{CONCLUSION}

The study found that generally more metadiscourse markers were utilised in the sermons of practice/ action dimension than in the two other themes. This seems to be due to the teaching nature of the practice sermons which are mainly delivered to educate and direct the listeners based on the Islamic creed.

In terms of the frequency of the interactive metadiscourse markers across the three themes, a number of significant distinctions were identified. Transition markers were performed similarly across the three themes of the selected sermons. On the other hand, frame markers showed a rather different pattern of usage. They were frequently deployed to announce the goals of the orators' speeches in the sermons of practice dimension. Significant variations were also observed in the distribution of the frequency of evidential markers. They were utilized by the orators primarily to relate the propositions to the scripture (Quran) as well as to life experiences particularly in the sermons of belief dimension. Such observation can be explained by the fact that the Quran is regarded to be the most authentic and authoritative source by the Muslims. Another form of evidentials, the prophet sayings, were also positioned noticeably in the sermons of spiritual and practice themes. This indicates the prominence placed on the significance of the Prophet's explanations and interpretations alongside the Quran by the Muslims; and how these two evidentials provide strong support to the explanations related to the spiritual and practice themes.

On the other hand, interactional metadiscourse markers behaved differently across the three themes of the selected sermons. In terms of frequency distribution of hedges and 
engagement markers, there were no significant differences across the themes (belief, practice, and spiritual). Nonetheless, boosters appeared to be used differently in the three themes. For example, modals were dominant in the spiritual sermons; the adverbs were more common in the practice and belief sermons; the quantifiers were frequently employed in the belief sermons; and verbs occurred most commonly in the practice sermons.

This study has provided further evidence on the inevitability of metadiscourse markers in contributing coherence to the text; in this case, in persuasive spoken discourse such as Friday sermons. Upon a closer scrutiny, the findings suggest that even within a specific genre, there may be differences in the choice of metadiscourse markers for different sermon themes. More specifically, the results of this study offer an indicative picture about the types of metadiscourse markers which may effectively serve the aims of particular theme of Islamic Friday sermon. It is hoped that this study will raise the attention of religious orators towards the role of the linguistics devices of metadiscourse in each particular theme of Islamic Friday sermons.

\section{ACKNOWLEDGMENT}

This research is supported by research grant coded GP-IPS/2017/9560800, Universiti Putra Malaysia.

\section{REFERENCES}

Abdel-Moety, D. M. (2019). A Metadiscursive Analysis of Arabic Religious Discourse. Journal of Semitic Studies, 64(1), 199-220.

Ädel, A. (2012). What I want you to remember is...: Audience orientation in monologic academic discourse. English Text Construction, 5(1), 101-127.

Addison, J. (1999). Reading Comprehension, (On-line) http://www.hio.ft.hanze.ntl thar/reading.htm

Albayrak, I. (2012). Friday sermons and the question of home-trained imams in Australia. Australian EJournal of Theology, 19(1), 29-42.

AlJazrawi, D. A., \& AlJazrawi, Z. A. (2019). The Use of Meta-discourse An Analysis of Interactive and Interactional Markers in English Short Stories as a Type of Literary Genre. International Journal of Applied Linguistics and English Literature, 8(3), 6677.

Azar, A. S., \& Hashim, A. (2019). The Impact of Attitude Markers on Enhancing Evaluation in the Review Article Genre. GEMA Online ${ }^{\circledR}$ Journal of Language Studies, 19(1). 153173.

Barlow, M. (2003). Concordancing and Corpus Analysis Using MP 2.2. Huston: Athelstan.

Blagojevic, S. (2004). Metadiscourse in academic prose: A contrastive study of academic articles written in English by English and Norwegian native speakers. Studies about Languages, 5(1), 1-7.

Boggel, S. (2009). Metadisocurse in Middle English and Early Modern English Religious Texts: A Corpus Based Study. Peter Lang.

Bunton, D. (1999). The use of higher level metatext in Ph.D theses. English for Specific Purposes, 18, 41-56.

Cavalieri, S. (2011). The Role of Metadiscourse in Counsels' Questions. In A. Wagner and L. Cheng (Eds), Exploring Courtroom Discourse: The Language of Power and Control (pp. 79-110). Ashgate Publishing Limited.

Crismore, A. (1984). The rhetoric of textbooks: Metadiscourse. Journal of Curriculum Studies, 16(3), 279-296.

Crismore, A., Markkanen, R., \& Steffensen, M, S. (1993). Metadiscourse in persuasive writing: 
A study of texts written by American and Finnish university students. Written Communication, 10(1), 39-71.

Dahl, T. (2004). Textual metadiscourse in research articles: A marker of national culture or of academic discipline? Journal of Pragmatics, 36(10), 1807-1825.

Davies, F. (1988). Reading between the lines: thematic choice as a device for presenting writer viewpoint in academic discourse. The ESPecialist, 9 (2), 173-200

Hashem, M. (2010). The ummah in the khutba: A religious sermon or a civil discourse?. Journal of Muslim Minority Affairs, 30(1), 49-61.

Hyland, K. (1998). Persuasion and context: The pragmatics of academic metadiscourse. Journal of Pragmatics, 30(4), 437-455.

Hyland, K. (2005). Metadiscourse: Exploring Interaction in Writing. London: Continuum.

Hyland, K. (2017). Metadiscourse: What is it and where is it going? Journal of Pragmatics, 113: $16-29$.

Hyland, K., \& Tse, P. (2004). Metadiscourse in academic writing: A reappraisal. Applied Linguistics. 25(2), 156-177.

Ilie, C. (2003). Discourse and metadiscourse in parliamentary debates. Journal of language and Politics, 2(1), 71-92.

Khedri, M. (2014). A Cross-Disciplinary Exploration of Metadiscourse in Experimental Research Articles. (Unpublished doctoral dissertation). Universiti Putra Malaysia, Malaysia.

Lee, J. J., \& Subtirelu, N. C. (2015). Metadiscourse in the classroom: A comparative analysis of EAP lessons and university lectures. English for Specific Purposes, 37(1), 52-62.

Loi, C. K., \& Lim, J. M. H. (2019). Hedging in the discussion sections of English and Malay Educational Research Articles. GEMA Online ${ }^{\circledR}$ Journal of Language Studies, 19(1), 36-61.

Mahmood, I. I., \& Kasim, Z. M. (2019). Interpersonal Metadiscursive Features in Contemporary Islamic Friday Sermon. 3L: The Southeast Asian Journal of English Language Studies, 25(1), 85 - 99.

Malmström, H. (2016). Engaging the congregation: The place of metadiscourse in contemporary preaching. Applied Linguistics, 37(4), 561-582.

Mellor, N., \& Rinnawi, K. (2016). Political Islam and Global Media: The Boundaries of Religious Identity. Abingdon: Routledge.

Mustafa, I., AlZayaat, A., Hamed, A.-Q., \& AlNajaar, M. (2004). Al-Mu'jam Al-Waseet. Cairo: Maktabat Al-Shorouq Al-Dawliyah.

Onay, A. (2004). Content analysis of Friday sermons-DIB* sermons in the year 1999. Íslami Araştırmalar Dergisi, 17, 1-13.

Paltridge, B. (2012). Discourse Analysis: An Introduction. London: Bloomsbury.

Tan, H. (2011). Metadiscourse Features in the Persuasive Essays of Undergraduate Writers. (Unpublished doctoral dissertation). Universiti Putra Malaysia. Malaysia.

Turiman, S., Abdullah, N., \& Noor, N. M. (2018). Spoken metadiscourse in Malaysian ESL job interviews. GEMA Online ${ }^{\circledR}$ Journal of Language Studies, 18(3). 135-152.

Vande-Kopple, W. (1985). Some exploratory discourse on metadiscourse. College Composition and Communication, 36: 82-93.

Whitehead, D., \& Whitehead, L. (2016). Sampling data and data collection in qualitative research. Nursing and midwifery research: Methods and appraisal for evidence-based practice, 111-126.

Williams, J. (1981). Style: Ten Lessons in Clarity and Grace. Glen-view: Ill.:Scott, Foresman \& Company. 


\section{ABOUT THE AUTHORS}

Israa Ismaeel Mahmood received her Master degree in linguistics from Universiti Putra Malaysia in 2019. Her main research interests include discourse analysis, genre analysis, and rhetorical analysis.

Zalina Mohd Kasim $(\mathrm{PhD})$ is an Associate Professor at the Department of English, Faculty of Modern Languages and Communication, Universiti Putra Malaysia. Her current research interests include cognitive stylistics, semiotics, applied linguistics, and discourse analysis. 